\title{
ECONOMIC EVALUATION OF MAINTAINING THE CAPACITY OF TRASH RACKS IN HYDRAULIC ENGINEERING STRUCTURES
}

\author{
Natalia Walczak ${ }^{1}$ \\ 1 Department of Hydraulic and Sanitary Engineering, Poznan University of Life Sciences, Piatkowska Str. 94A, \\ 60-649 Poznań, Poland. e-mail: nwalczak@up.poznan.pl
}

Received: 2017.01 .23

Accepted: 2017.03 .07

Published: 2017.05.02

\begin{abstract}
Considering limited capabilities of obtaining energy in a traditional way from coal combustion and the requirements of the European Union, other alternative energy sources should be sought. They have been increasingly used by business entities and individual investors and are designed to provide financial profits, which will be ensured only with correct operation of the energy system. One of the examples of alternative energy sources application is the construction of small hydropower plants, where the efficiency of all elements included is of great importance. Article analyses of financial losses incurred by owners of power plants when the energy system lacks $100 \%$ capacity of the inlet channel. Material that accumulates on SHP trash racks might be analysed in two ways: biologically (these are screenings - as in wastewater treatment plants) and hydraulically.
\end{abstract}

Keywords: trash racks, Small Hydropower Plant, economic

\section{INTRODUCTION}

Inland waters flowing down rivers or collected in reservoirs by damming structures provide enormous resources of kinetic energy that can be converted into e.g. mechanical or electrical energy. In addition to their core objectives, river damming and regulation should be adjusted accordingly to ensure that the accumulated energy is used and converted by means of hydraulic turbines into electricity. Compared with traditional methods (thermal power plants), hydropower energy technologies have the following advantages: slightly lower investment costs of the facility and significantly reduce costs of electricity production. Additionally, hydropower plants can be almost completely automated. However, the strongest point is that they do not consume large amounts of fuel, whose combustion process causes various types of pollution to the environment. Hydroelectric power plants can be divided with regard to: flow rate levelling, flow rate characteristics, terms of cooperation with the energy system, hydraulic gradient, power and geographical location. Considering the location of small hydropower facilities, they categorize into four types: power plants on small rivers, power plants of derivation-type (on side channels/ducts), power plants of mixed-type and power plants installed on irrigation channels.

In order to determine basic parameters when designing a small hydroelectric plant (SHP), it is required to carry out appropriate preparatory actions [Koralewski and Ligocki, 2004], including hydrological, hydraulic and energy calculations.

Hydrological calculations include the analysis of multi-year observations of states and rate flows in a specific section (rating curve), which can be used to determine the characteristics of catchment area and water regime.

Hydraulic calculations concern the determination of turbine discharge and idle flow rate.

Hydroelectric calculations consist in determining numerous values such as: flow rate, hydraulic gradient, power production capacity, working time, coefficients, etc. [Arkuszewski et al. 1991]. 
The total energy reserve of a watercourse in any chosen section is defined with Bernoulli's equation.

$$
\text { const }=g h+\frac{p}{\rho}+\frac{v^{2}}{2}
$$

where: $V$ - water velocity $[\mathrm{m} / \mathrm{s}]$

$$
\begin{aligned}
& g \text { - acceleration due to gravity }\left[\mathrm{m} / \mathrm{s}^{2}\right] \\
& h \text { - height }[\mathrm{m}] \\
& p \text { - pressure } \\
& \rho \text { - water density }\left[\mathrm{kg} / \mathrm{m}^{3}\right] .
\end{aligned}
$$

This dependency on SHP power is shown graphically in Fig. 1, where water levels before and after the construction of the dam are indicated. The designations specify respectively: $\mathrm{H}_{1}$ and $\mathrm{H}_{2}$ - assumed depths of the centre of gravity of water mass at the top and bottom levels, $h_{1}$ and $h_{2}$ - depths of the centre of gravity of water mass below the water surface, $\mathrm{H}_{\mathrm{A}}, \mathrm{H}_{\mathrm{B}}$ - levelling of the water surface above the reference water level.

It is possible to designate the theoretical amount of energy E held in water flowing between two sections ( 1 and 2), which may be symbolically written as follows [Koralewski and Ligocki, 2004]:

$$
\begin{aligned}
& E_{1}=\left[g \cdot H_{1}+\frac{p_{1}}{\rho}+\frac{v_{1}^{2}}{2}\right] \rho \cdot V \\
& E_{2}=\left[g \cdot H_{2}+\frac{p_{2}}{\rho}+\frac{v_{2}^{2}}{2}\right] \rho \cdot V
\end{aligned}
$$

where: $H_{1}, H_{2}$ - elevation of cross-sections $\mathrm{A}$ and $\mathrm{B}$ above any given reference water level [m] $p_{1}, p_{2}-$ pressure on the water table $[\mathrm{Pa}]$ $v_{1}, v_{2}$ - water velocity $[\mathrm{m} / \mathrm{s}]$ $V$ - volume of flowing water.
In addition, the product $g H$ is the energy of location (potential value), the quotient $\frac{p}{\rho}$ is the energy of pressure, and $\frac{v^{2}}{2}$ is the energy of velocity (kinetic).

The energy between two sections is

$$
\begin{gathered}
E_{12}=E_{1}-E_{2}= \\
{\left[g\left(H_{1}-H_{2}+\frac{p_{1}-p_{2}}{\rho}+\frac{v_{1}^{2}-v_{2}^{2}}{2}\right)\right] \rho \cdot g}
\end{gathered}
$$

Part of this energy is used to overcome the internal friction of water masses, overcome the friction of water when it contacts with the watercourse surface, create local whirls and jumps and erode the river bed. The remaining part of energy obtained from the high value of hydraulic gradient (watercourse damming) can be used in hydraulic turbines. The centres of gravity of water masses in sections 1 (upper) and 2 (lower) are at $\mathrm{H}_{1}$ and $\mathrm{H}_{2}$ levels respectively, where the difference in levels determines the value of hydraulic gradient. After taking into account hydrostatic pressure in the analysed sections, the amount of energy that the turbine can use is as follows:

$$
E_{12}=\left[g \cdot H+\frac{v_{A}^{2}-v_{B}^{2}}{2}-g \cdot \sum h s t r\right] \rho \cdot V
$$

Effective energy is written in square brackets, where: $g \cdot H$ - potential energy of water in the upper area $\frac{v_{1}^{2}}{2}-$ kinetic energy due to movement of water in the upper area at $\mathrm{v}_{1}$ $\frac{v_{2}^{2}}{2}-$ kinetic energy due to movement of water in the upper area at $\mathrm{v}_{2}$

g $\sum$ Hstr- energy loss due to hydraulic resistivity in the turbine [Koralewski and Ligocki, 2004].

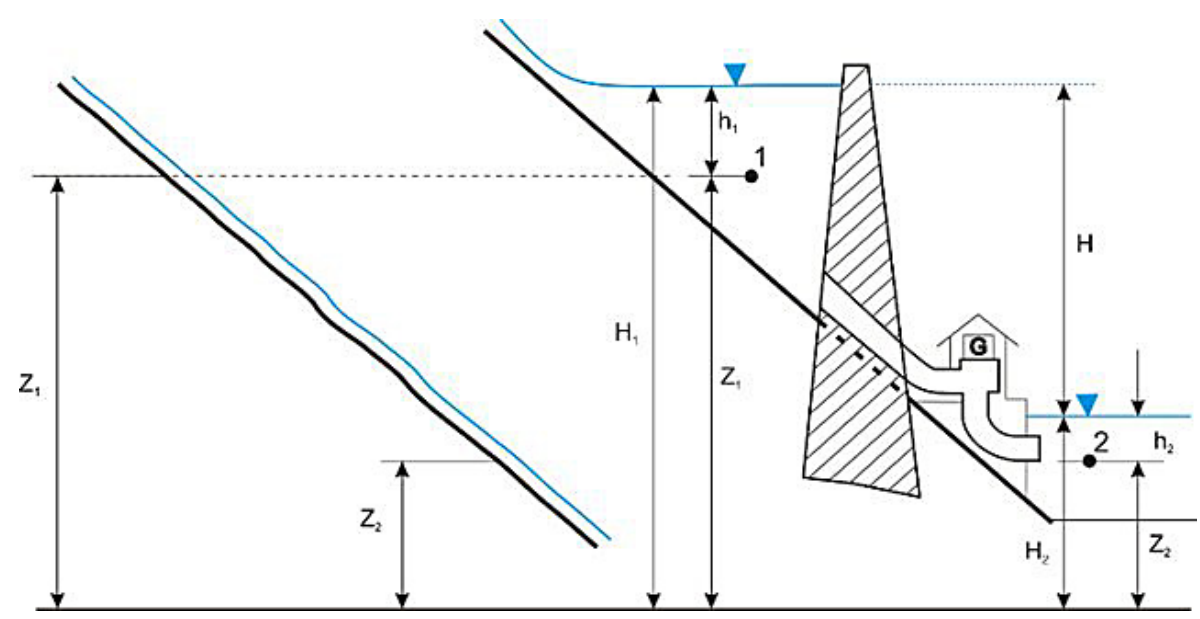

Figure 1. Cross-section of the riverbed before and after constructing the dam 
If potential energy is converted into electrical energy, the efficiency of this process should be considered. Correspondingly, the dependency on the electrical energy is as follows:

$$
E_{e l}=g \cdot H \cdot V \cdot \rho \cdot \eta_{t} \cdot \eta_{p} \cdot \eta_{g}
$$

If the difference in water levels concentrates within a small area (short length of supply lines), pressure drops in lines supplying water to the turbine can be omitted. Additionally, water velocities in front and behind the damming are similar in general, and therefore potential energy plays a fundamental role in changing the energy of water into electricity [Koralewski and Ligocki, 2004]. Then, the dependency specifying the amounts of useful energy can be written in a form:

$$
E_{u}=g \cdot H
$$

Hydraulic power $(\mathrm{P})$ expressed in $\mathrm{kW}$ is designated from the quotient of electrical energy $\mathrm{E}_{\mathrm{el}}$ and time $(t)$. Furthermore, the efficiency of the following elements of a turbine aggregate should be taken into account i.e. turbines $\left(\eta_{\mathrm{t}}\right)$, gear $\left(\eta_{\mathrm{p}}\right)$ and generator $\left(\eta_{\mathrm{g}}\right)$. Flowing water volume $(\mathrm{V})$ per second $(\mathrm{t})$ is taken as the value of turbine discharge $(\mathrm{Q})$; and as a result, hydraulic power can be written as follows:

$$
P=g \cdot H \cdot Q \cdot \rho \cdot \eta_{t} \cdot \eta_{p} \cdot \eta_{g}
$$

Finally, active power $(\mathrm{P})$ generated by hydraulic power plants can be determined in general:

$$
\mathrm{P}=9,81 \cdot \mathrm{Q} \cdot \mathrm{H} \cdot \eta
$$

where: $\eta$-efficiency coefficient of the turbine aggregate, which is the product of efficiency values for: turbine, gear and generator.

For small power plants the value takes $0,5-0,7$, for larger ones it is $0,75-0,85$ [Arkuszewski et al. 1991]. Generally, it is assumed that the efficiency for modern hydroelectric power plants (turbine, generator, drive, transformer) is approx. $75-85 \%$, while for renovated hydropower facilities of older technology it remains between $55 \%$ and $70 \%$. Over the years, the efficiency regularly decreases due to i.e. abrasion and wear [Lampl, 2009].

To summarize, power generated by hydroelectric power plants that use the energy of rivers depends on the value of hydraulic gradient (the difference in levels in front and behind the turbine), the size of turbine discharge $\mathrm{Q}$ as well as the efficiency of hydraulic turbine, gear and generator equipment [Marecki, 2000].

If there is no full or certain hydrological information, it is possible to estimate the annual energy production at the conceptual stage of a power plant investment. Such an estimation requires multiplying the installed hydraulic power (formula 5) by the value of working time, reducing coefficient related to the type of a river, levelling of flow rates as well as the dependency between turbine discharge and flow rate in the river. This coefficient varies from 0.5 for mountain rivers to 0.7 for lowland rivers [Arkuszewski et al. 1991].

\section{MATERIALS AND METHODS}

Small hydropower plants (SHP) are technical facilities that are part of alternative energy sources [Paish, 2002]. They are primarily characterised by low unit power, in Poland it is the value below $5 \mathrm{MW}$. They are often constructed on existing barrages. Electrical current produced by these plants is used to meet local demand. Considering the exploitation of SHPs, it is important to ensure a stable flow rate through hydraulic turbines.

Legal grounds for the development of small hydropower plants in Poland (SHP is an accepted abbreviation) were established when the Council of Ministers adopted the resolution no. 192 on the development of small hydropower on 7 September 1981. The resolution allowed operators from other industries, and hence individual users, to implement and use SHPs of up to $5 \mathrm{MW}$ [Paska and Staniszewski, 1994]. Hydroelectric potential of rivers in Poland is currently used only in $16 \%$, while many other European countries exploit it to much greater extent, even more than $80 \%$, e.g. Germany $-70 \%$, France $-82 \%$, Slovakia $-59 \%$, Switzerland - 92\%, Austria - 69\%, Spain - 79\% [Solski, 2012]. Under the Polish hydrological conditions hydropower can be used mainly in hydropower plants of several hundred kW [Pistolek and Rossa, 2014]. As specified in the European Union guidelines, in 2020 the production of electricity from renewable energy sources in Poland is expected to be not less than $15 \%$ of the total energy produced. In the event of failure to comply with the requirement, sanctions might be imposed on the country. Currently, this figure is only about $7 \%$. According to the Act of 18 July 2001 on Water Law (Art. 2) administrators of rivers are obliged to create conditions for the use of water for energy production. At present, there is 
no information what theoretical potential is available. (According to WZMiUW (Provincial Land Melioration And Water Units Board) there are more than 15000 water impoundment systems in Poland including weirs, barrages and valves). It is not known how many of them are used for energy production purposes, if they are fit for practical use, or what is their technical condition [Mazurkiewicz, 2015].

Aggidis et al. (2010) analysed SHP equipment costs depending on the applied turbine set. SHP revenues consist of earnings from the energy produced and the certificates of origin issued for ecological energy, i.e. renewable green energy. Currently, hydropower plants in Poland produce approx. $1500 \mathrm{GWh}$ of energy per year, which saves almost 1000000 tonnes of coal and reduces the amount of harmful substances acting on the environment. In addition, producers of such energy obtain the certificates of origin i.e. green certificates, which are traded at the Polish Power Exchange. As a result, green certificates obtained by operators producing renewable electrical energy provide them with another prospective source of income, apart from revenues from electricity sale. Thanks to this clean energy technology, producers can earn much more [Solski, 2012].

The specificity of investing in micro-hydropower is associated with the reduction in investment costs (hydro-generator purchase costs, its installation and commissioning). This approach may only be justified at the preliminary design stage and it can be attributed to a comparative analysis of purchase cost of a particular turbine type. Considering the design of a turbine, Kaplan turbines are the most expensive, Francis and propeller turbines are more cost-competitive, while cross-flow turbines are the most economical solution (Michell-Banki). For the above reasons (or in the scope of low hydraulic gradient values) propeller and cross-flow turbines are recommended for use in micro power stations. However, the absolute differences in prices, particularly of microturbines, are not clear, which may result from the fact that approx. half the price of a turbine is the cost of its control equipment [Raduch 2008].

An example cost of SHP is presented based on the presentation by the representatives of MEW S.A. (Marcin Markiewicz). It costs between 10-15 million PLN to construct a small hydropower plant of $1 \mathrm{MW}$, with the option to secure $60 \%$ of the total invested amount from EU funding. SHP service life is estimated for 100 years.
Power plants of this type can produce up to 6000 MWh of electricity annually, whose cost is about 2500000 PLN. Operating costs of power plants, less than $10 \%$ of income, also appear to be preferable in economic terms. Conclusively, the cost of hydropower plant design and construction (in one year) returns within 3 to 6 years depending on the price and parameters of the location! For comparison, the cost of SHP equipment construction proposed by Solski, without the cost of acquiring land rights and rights to use a watercourse, ranges between 3,000 and 10000 PLN per $1 \mathrm{~kW}$ of installed power (Solski, 2012). Solski considers flow rate values, hydraulic gradient values and numerous other coefficients in his profitability algorithm related to the construction of SHP. These include i.e. SHP power capacity, the conversion of energy production from $1 \mathrm{MWh}$ to $\mathrm{KW}$, the rate of return (obtained from the budgetary analysis), revenues and financial performance of the project. According to the standard proposed by Solski, SHP power [kW] multiplied 20,000 times will give an indicative cost of the project.

The obstacles in the construction of SHPs are significant costs of mechanical and electrical equipment, which can be as much as $50 \%$ of the total investment cost. The small hydropower technology is modelled on large facilities, and therefore, a cost effective design of a SHP requires adjusting some of the available technological solutions (Solski, 2012). A key element of hydrotechnical facility, exampled by small hydropower, is its intake, which should limit the amount of material (dragged bed load and suspended load) that enters the flow system of the power plant. For this purpose, inlets are fitted with protective trash racks (fine and coarse) made of steel bars [Berthold, 2009]. Parallelly fixed, equally spaced and of base construction, they are to withstand total water pressure without excessive distortion. The spacing between bars depends on the type of installed turbine, with values ranging: $20-30 \mathrm{~mm}$ for Pelton turbines, $40-50 \mathrm{~mm}$ for Francis turbines and $80-100 \mathrm{~mm}$ for Kaplan turbines, respectively. When designing trash racks, it is necessary to determine specific hydraulic losses because they are responsible for a real reduction in the value of electricity production. These losses result not only from the spacing of bars, their shape and the technical condition of the inlet chamber, but also from plant debris, its nature, and the quantity of accumulated material that effectively limits the water flow. Hydraulic losses at the inlet and losses re- 
sulting from the roughness of the inlet section can be excluded. Therefore, the increase in hydraulic loss values caused by the coverage of an opening with material deposited on trash racks becomes highly significant. Improper operating conditions (infrequent cleaning service of trash racks) may lead to the increase comparable to, or sometimes higher than, the total value of all losses resulting from the trash rack design [Walczak et al. 2014]. The increase in flow velocity values at trash racks that depends on size reductions has also a major impact. Even $10 \%$ coverage of a trash rack opening, under adverse conditions of cross-sectional geometry, may bring losses reaching up to $10 \mathrm{~cm}$, which results in financial loss.

In order to indicate exact financial losses caused by clogging trash racks with debris, there was carried out the financial analysis of profits for SHP characterised by specific hydraulic gradient and water flow rate values. For analytical purposes, the hydraulic gradient was assumed to be $5 \mathrm{~m}$ and its value was reduced twice $(4.8 \mathrm{~m}$ and $4.6 \mathrm{~m}$ ) due to the lack of conveyance in the lower area as a result of uncontrolled growth of vegetation. Additionally, the flow rate was decreased gradually, leading to its maximum reduction by $30 \%$. For each case analysed calculations also included the deterioration of SHP equipment efficiency by changing efficiency coefficient values. Table 1 shows the profit calculated empirically on the assumption that a hydraulic power plant operates only three hours a day, and the price of $\mathrm{kWh}$ is 0.55 PLN. 3-hour work cycle of a hydraulic facility applies to large power plants and results from daily demand for energy. Considering SHPs, a work cycle may arise from the need to manage energy demand in the system, performing a functionality that reduces power fluctuations [Gondowicz et al. 1975]. On the basis of the report containing the juxtaposition of quantitative data related the operation of the National Energy System in 2011, a 3-hour cycle of SHP work is fully justified. In winter energy demand increases from $4 \mathrm{pm}$ to $8 \mathrm{pm}$, while in summer it reaches its peak between $8 \mathrm{pm}$ and $10 \mathrm{pm}$.

By analysing Fig. 2 if the flow rate decreases gradually, the difference in profit between power plants with the highest values of conveyance (max. values of hydraulic gradient and flow rate) and power plants with least favourable characteristics (flow rate reduced by $30 \%$ and hydraulic gradient by $8 \%$ ) financial losses amounts to approx. 50\%. Investors will make less profit if they maintain constant hydraulic gradient values while decreasing the capacity. It can be expected that the level of profit will be reduced by $13 \%$ (for optimal parameters).

Financial losses resulting from clogging trash racks with debris can be overcome in a readily accessible and prompt manner. A sufficient preventive measure is to clean trash racks from plant debris systematically, whose species composition and quantity depend largely on vegetation periods. The greatest problem might be the necessity to dispose SHP trash rack material in the landfill, since it is classified under the waste management code of 190801 . Although it is an organic material with distinctive characteristics in terms of the standard material taken from trash racks at sewage treatment plants, the legislator has not foreseen a different category for this type of waste. It is assumed that the waste is biodegradable and

Table 1. Profit statement (in thou) for SHP electricity production depending on changes in flow rate and hydraulic gradient values per year

\begin{tabular}{|c|c|c|c|c|c|c|c|c|c|c|}
\hline $\begin{array}{c}\text { Flow/ hydraulic } \\
\text { gradient }\end{array}$ & 65 & 63.7 & 63.05 & 62.4 & 61.75 & 61.1 & 60.45 & 59.8 & 59.15 & 58.5 \\
\hline 5 & 1440 & 1411 & 1397 & 1382 & 1368 & 1354 & 1339 & 1325 & 1310 & 1296 \\
\hline 4.8 & 1290 & 1265 & 1252 & 1239 & 1226 & 1213 & 1200 & 1187 & 1183 & 1161 \\
\hline 4.6 & 1060 & 1039 & 1028 & 1018 & 1007 & 996 & 986 & 975 & 965 & 954 \\
\hline $\begin{array}{c}\text { Flow/ hydraulic } \\
\text { gradient }\end{array}$ & 57.9 & 57.2 & 56.6 & 55.9 & 55.3 & 54.6 & 54.0 & 53.3 & 52.7 & 52.0 \\
\hline 5 & 1282 & 1267 & 1253 & 1238 & 1224 & 1210 & 1195 & 1181 & 1166 & 1152 \\
\hline 4.8 & 1148 & 1135 & 1123 & 1110 & 1097 & 1084 & 1071 & 1058 & 1045 & 1032 \\
\hline 4.6 & 943 & 933 & 922 & 912 & 901 & 890 & 880 & 869 & 859 & 848 \\
\hline $\begin{array}{c}\text { Flow/ hydraulic } \\
\text { gradient }\end{array}$ & 51.4 & 50.7 & 50.1 & 49.4 & 48.8 & 48.1 & 47.5 & 46.8 & 46.2 & 45.5 \\
\hline 5 & 1138 & 1123 & 1109 & 1094 & 1080 & 1066 & 1051 & 1037 & 1022 & 1008 \\
\hline 4.8 & 1019 & 1006 & 994 & 981 & 968 & 955 & 942 & 929 & 916 & 903 \\
\hline 4.6 & 837 & 827 & 816 & 806 & 795 & 784 & 774 & 763 & 753 & 742 \\
\hline
\end{tabular}




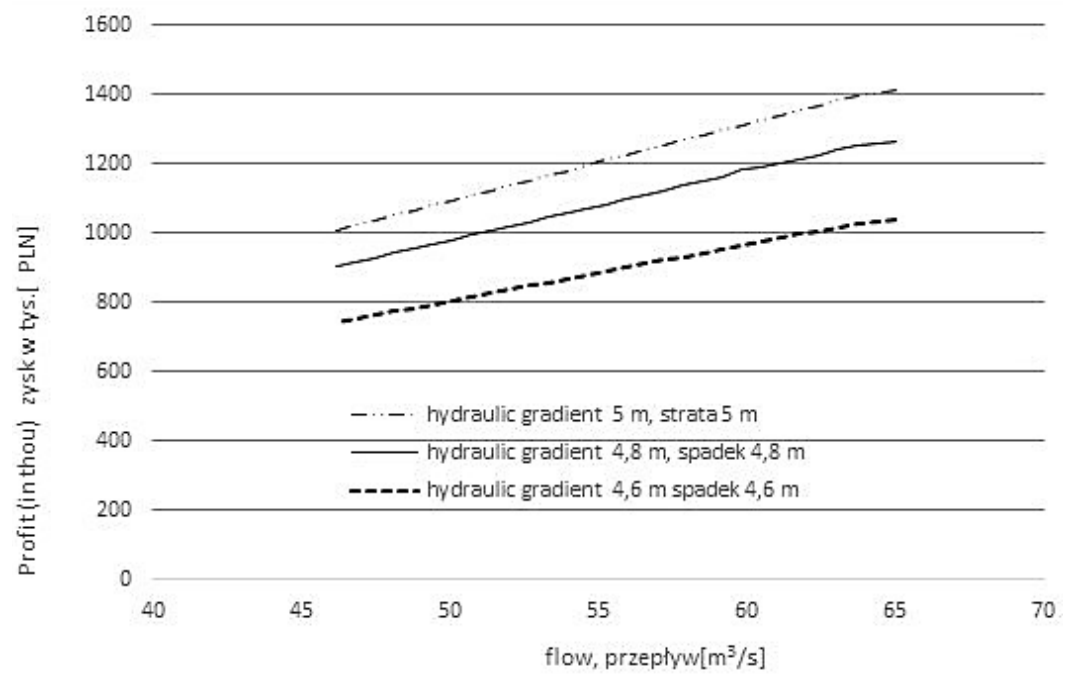

Figure 2. Profit of SHP producing energy depending on the hydraulic gradient

can be processed efficiently in composting, fermentation or mechanical-biological technologies.

Another analysis applies only to losses that result from a decrease in conveyance and a change in efficiency coefficient as well as losses limited to a change in hydraulic gradient (Table 2).

\section{CONCLUSIONS}

The examples presented in this paper cover relevant aspects of an appropriate selection of trash racks and their proper use. In the case of SHPs operating with low hydraulic gradient values the above considerations can make a huge difference in terms of efficiency and costeffectiveness of electricity production. The requirements for trash rack openings postulated by ichthyologists may result in very low costeffectiveness of hydroelectric power plants, particularly poorly designed and operated facilities of this type. Incorrect operation of the upper (trash racks) and lower areas may cause measurable financial losses. In SHP's use, the building and installation infrastructure deteriorate, which decreases potential profits, however these aging processes are inevitable and remain behind the control of operators. The situation is different with the lack of conveyance that results from improper maintenance of facilities.

Table 2. Juxtaposition of losses resulting from changes in efficiency coefficients of the turbine aggregate and hydraulic gradient values

\begin{tabular}{|l|c|c|c|c|c|c|c|c|c|c|}
\hline Flow/loss & 65 & 63.7 & 63.05 & 62.4 & 61.75 & 61.1 & 60.45 & 59.8 & 59.15 & 58.5 \\
\hline Efficiency 0.75 & 0 & 29 & 43 & 58 & 72 & 86 & 101 & 115 & 130 & 144 \\
\hline Efficiency 0.7 & 0 & 26 & 13 & 26 & 39 & 52 & 65 & 77 & 82 & 103 \\
\hline Efficiency 0.65 & 0 & 21 & 11 & 21 & 32 & 42 & 53 & 64 & 74 & 85 \\
\hline Hydraulic gradient 4.8 & 150 & 147 & 145 & 144 & 142 & 141 & 139 & 138 & 128 & 135 \\
\hline Hydraulic gradient 4.6 & 380 & 373 & 369 & 365 & 361 & 357 & 354 & 350 & 346 & 342 \\
\hline Flow/loss & 57.85 & 57.2 & 56.55 & 55.9 & 55.25 & 54.6 & 53.95 & 53.3 & 52.65 & 52 \\
\hline Efficiency 0.75 & 158 & 173 & 187 & 202 & 216 & 230 & 245 & 259 & 274 & 288 \\
\hline Efficiency 0.7 & 116 & 129 & 142 & 155 & 168 & 181 & 194 & 206 & 219 & 232 \\
\hline Efficiency 0.65 & 95 & 106 & 117 & 127 & 138 & 148 & 159 & 170 & 180 & 191 \\
\hline Hydraulic gradient 4.8 & 133 & 132 & 130 & 129 & 127 & 126 & 124 & 123 & 121 & 120 \\
\hline Hydraulic gradient 4.6 & 338 & 335 & 331 & 327 & 323 & 319 & 316 & 312 & 308 & 304 \\
\hline Flow/loss & 51.35 & 50.7 & 50.05 & 49.4 & 48.75 & 48.1 & 47.45 & 46.8 & 46.15 & 45.5 \\
\hline Efficiency 0.75 & 302 & 317 & 331 & 346 & 360 & 374 & 389 & 403 & 418 & 432 \\
\hline Efficiency 0.7 & 245 & 258 & 271 & 284 & 297 & 310 & 323 & 335 & 348 & 361 \\
\hline Efficiency 0.65 & 201 & 212 & 223 & 233 & 244 & 254 & 265 & 276 & 286 & 297 \\
\hline Hydraulic gradient 4.8 & 118 & 117 & 115 & 114 & 112 & 111 & 109 & 108 & 106 & 105 \\
\hline Hydraulic gradient 4.6 & 300 & 297 & 293 & 289 & 285 & 281 & 278 & 274 & 270 & 266 \\
\hline
\end{tabular}




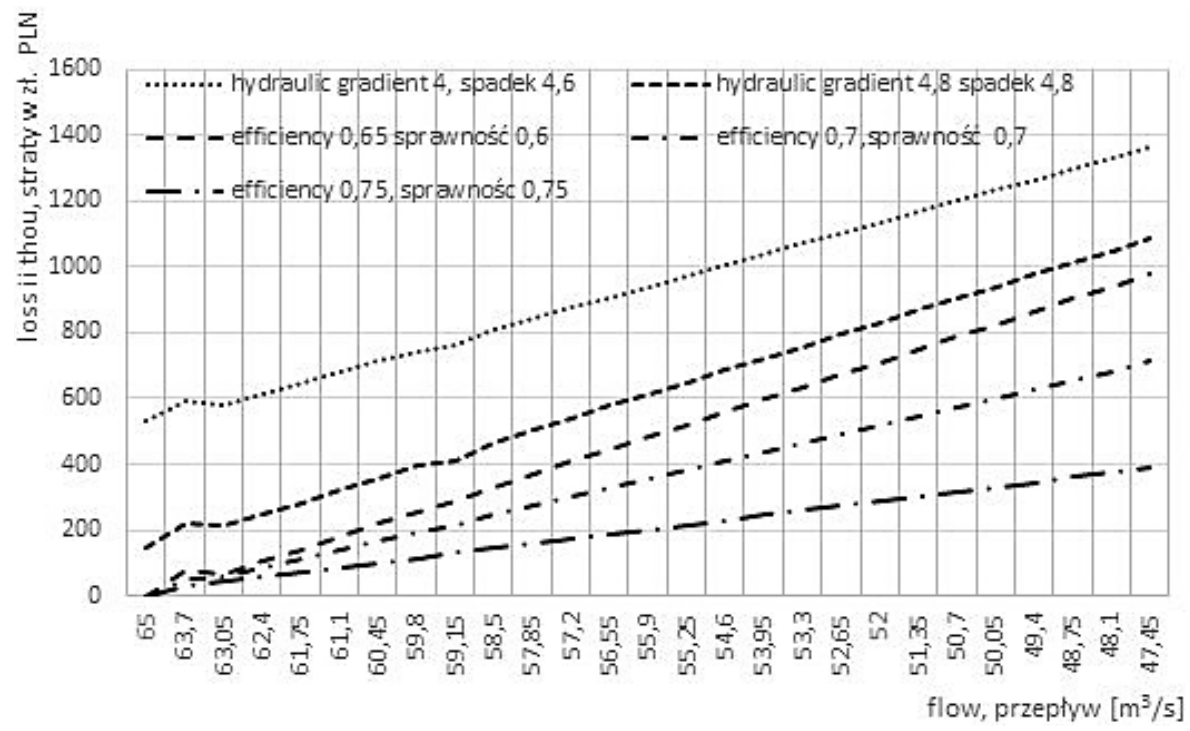

Figure 3. Loss of SHP producing energy depending on hydraulic gradient values per year

The main advantage of small hydropower technology is the guarantee that the electricity produced will be purchased at cost-effective prices. The analysis in this paper allows for determining the amount of financial losses resulting from improper use of the upper and lower areas of the river. In consequence, it translates into lower financial profits.

\section{REFERENCES}

1. Aggidis, G. A., Luchinskaya, E., Rothschild, R., and Howard, D. C. (2010). The costs of small-scale hydro power production: Impact on the development of existing potential. Renewable Energy, 35(12), 2632-2638.

2. Arkuszewski A., Kiciński T., Romańczyk Cz., Żbikowski A., 1991; budownictwo wodne cz. 3. Podręcznik dla technikum. Wydawnictwo Szkolne i pedagogiczne, Warszawa 1991r

3. Berthold, Helena (2009). Untersuchung zur Umsetzung der Hessischen Fischereiverordnung im Hinblick auf die Installation von Feinrechen mit 15 $\mathrm{mm}$ Stababstand und den Fischabstieg (Doctoral dissertation, Diplomarbeit am FB Bauingenieurwesen (unveröffentlicht), Kassel).

4. Gondowicz A., Kiciński T., Żbikowski A; (1975), Budownictwo wodne. Wydawnictwo szkolne i pedagogiczne Chorzów

5. Karolewski B; Ligocki P., Wyznaczanie parametrów małej elektrowni wodnej. Prace Naukowe Instytutu Maszyn, Napędów i Pomiarów Elektrycznych Politechniki Wrocławskiej, 2004, 56.

6. Marecki J., Podstawy przemian energetycznych, WNT, Warszawa 2000

7. Paish, O. (2002). Small hydro power: technology and current status. Renewable and sustainable energy reviews, 6(6), 537-556.

8. Paska J., Staniszewski A., Podstawy elektroenergetyki. Metody wytwarzania energii elektrycznej,Ofic. Wyd. Pol. Warsz., Warszawa 1994

9. Pistolek P i Rossa R.; (2014); Male elektrownie wodne jako źródło energii odnawialne. Rynek energii 2 (111)-2014 str. 75-80

10. Raduch J, (2008) Turbiny wodne - mikro elektrownie Czysta Energia 2/2008

11. Solski W. 2012, Małe elektrownie wodne - warto cenić wartość, http://www.ptrm.pl/aktualnosci/ warsztat-wyceny/male-elektrownie-wodne-wartocenic-wartosc

12. Lampl J 2009 Poprawa wydajności turbin wodnych GLOBEnergia 2/2009, ,Schubert Elektroanlagen $\mathrm{GmbH}$,

13. Walczak N., Kałuża T., Hämmerling M., Zawadzki P., Walczak Z. 2014. Straty hydrauliczne na kratach spowodowane materiałem organicznym unoszonym przez wodę, ,Acta Scientiarum Polonorum" Formatio Circumiectus. Z. 13. s. 247-258.

14. Markiewicz M (2015) prezentacja firmy dla inwestorów http://www.sii.org.pl/static/img/003021/ MEW_prezentacja.pdf 